\title{
ASMO-ohjelman alkio- ja valintatulokset
}

\author{
Terhi Vahlsten ${ }^{1)}$, Terttu Vanhamäki ${ }^{1)}$, Juha-Pekka Seppänen ${ }^{1)}$, Hannu Myllymäki ${ }^{1)}$ ja Jaana Peippo ${ }^{2)}$ \\ 1)Alkiokeskus Oy,Urheilutie 6,PL 40,01301Vantaa, etunimi.sukunimi@mtt.fi.hannu.myllymaki@faba.fi \\ ${ }^{2)}$ MTT, Maa-ja elintarviketalouden tutkimuskeskus, Kotieläintuotannon tutkimus, 31600 Jokioinen, \\ jaana.peippo@mtt.fi
}

\section{Johdanto}

ASMO-ydinkarja perustettiin syksyllä 1997, tavoitteena alkionsiirtoon pohjautuvan keskitetyn ayrshire-rotuisen jalostuskarjan perustaminen. Karjan perussukupolvi hankittiin neljän vuoden aikana ostamalla sekä Suomen että Ruotsin parhaita tiineitä ja nuoria hiehoja sekä huuhtelemalla peruspopulaation parhaita lehmiä. ASMO-ydinkarja on Alkiokeskus Oy:n ja MTT:n yhteistyöhanke.

ASMO-jalostusohjelmaa perustettaessa tärkeimmiksi tavoitteiksi asetettiin lehmien testaus ensikkokauden aikana samanlaisissa ruokinta- ja hoito-olosuhteissa sekä lehmien valintaintensiteetin optimointi huomioiden käytettävissä olevien lisääntymistekniikoiden tehokkuus. Ydinkarjan valintaohjelmavaihtoehtoja tutkittiin simuloimalla vastaavia ohjelmia tietokoneella. Tavoitteena oli tutkia, onko ASMO-ohjelman tyyppisessä jalostusohjelmassa mahdollista saavuttaa nopeampaa perinnöllistä edistymistä kuin perinteisessä keinosiemennysjalostusohjelmassa. Alustavat tulokset osoittivat, että ydinkarjassa perinnöllinen edistyminen voi olla jopa 48 - $65 \%$ nopeampaa kuin keinosiemennysjalostuksessa (Pakula ym. 1998). Simulaatiotutkimuksen malleja kehitettiin edelleen niin, että perinnöllinen edistyminen olisi mahdollisimman nopeaa, mutta samalla riskit eivät nousisi liian suuriksi. Jalostusohjelman riskiä voidaan kuvata mm. sukusiitosasteen muutoksen avulla. Kun sukusiitosasteen muutokselle asetettiin tietyt rajat, parhaimmiksi osoittautuivat ohjelmat, joissa valintaintesiteetti oli melko alhainen, lehmä tai hieho paritettiin useamman kuin yhden sonnin kanssa, käytettiin jälkeläisarvosteltuja sonneja ja rajoitettiin jalostukseen otettavien täys- ja puolisisarten määrää (Strandén ym, 2001; Korpiaho ym, 2001). Sukupolvenväli osoittautui tärkeäksi tekijäksi, sillä sonnipuolella sen lyhentäminen lisäsi riskejä, koska arvosteluvarmuus heikkeni (Parkkonen ym. 2000). Lehmäpuolella sukupolvenväliä voidaan kuitenkin lyhentää lisäten siten perinnöllistä edistymistä arvosteluvarmuuden kärsimättä.

Simulaatiotutkimusten perusteella ASMO-ydinkarjassa on päädytty toteuttamaan hiehohuuhteluohjelmaa, jossa hiehot huuhdellaan noin vuoden ikäisinä kaksi kertaa, jonka jälkeen ne tiineytetään. Eläinten valinta perustuu pääasiassa ensikkokauden testitulokseen, jossa huomioidaan eläimen jalostusarvo, rakenne-, käyttö- ja terveysominaisuudet. Ensikkokauden aikana karsitaan noin puolet ensikoista. Lopullinen ASMO-emien eli alkioiden luovuttajalehmien valinta tehdään toisen poikimisen jälkeen. Tällöin valitulla lehmällä on jo kasvamassa tyttäriä hiehohuuhteluiden ansioista, jotka otetaan mukaan jalostusohjelmaan. Tavoitteeksi on asetettu, että 70-80 hiehoa huuhdellaan vuosittain ja 15-20 lehmää valitaan alkioiden luovuttajiksi. Näin ollen joka neljäs hiehohuuhteluista syntyvä vasikka uudistaa ydinkarjan eläinainesta.

\section{Alkiotuloksia \\ Huuhtelumäärät ja alkiosaanto}

ASMO-ydinkarjassa huuhdellaan pääasiassa hiehoja. Hiehot huuhdellaan kahteen kertaan 13-15 kuukauden iässä. Vuonna 2002 syntyneiden hiehojen keski-ikä ensimmäisen huuhtelun aikana oli 13,9 kuukautta (vaihteluväli 12 - 18,5 kk). Huuhdeltavien hiehojen samoin kuin hiehohuuhteluidenkin määrä on noussut. Vuonna 2002 huuhdeltiin yhteensä 86 hiehoa ja kokonaisuudessaan tehtiin 152 huuhtelua hiehoille (taulukko 1), joten hiehohuuhteluiden osalta on saavutettu tavoite huuhdella vuosittain 70-80 hiehoa. Myös alkionsaanto on noussut ja hiehohuuhteluista saatiin keskimäärin 6,9 (vaihteluväli 0 - 38) siirtokelpoista alkiota huuhtelua kohti vuonna 2002.

ASMO-ydinkarjassa huuhdeltavat lehmät ovat toisen poikimisen jälkeen valittuja alkioiden luovuttajalehmiä, joilta pyritään saamaan 30-60 siirtokelpoista alkiota. Keskimäärin yhdeltä luovuttajalta on saatu 32,8 siirtokelpoista alkiota (vaihteluväli 0-64) ja luovuttajille on tehty keskimäärin 4,4 huuhtelua (vaihteluväli $0-8$ ). Lehmähuuhteluiden alkiosaanto on ollut viime vuosina todella hyvä ja useimmat luovuttajat ovat poistuneet alkiotuotannosta nopeasti. 
Taulukko 1. Hieho- ja lehmähuuhteluiden määrät ja alkiosaanto (siirtokelpoisia/huuhtelu) 1999-2003 (30.11.2003 asti).

\begin{tabular}{lccrrr}
\hline Huuhtelumäärät & $\mathbf{1 9 9 9}$ & $\mathbf{2 0 0 0}$ & $\mathbf{2 0 0 1}$ & $\mathbf{2 0 0 2}$ & $\mathbf{2 0 0 3}$ \\
\hline Hiehohuuhtelut & 66 & 109 & 103 & 152 & 122 \\
Lehmähuuhtelut & 5 & 36 & 32 & 37 & 20 \\
\hline Alkiosaanto & & & & & \\
\hline Hiehot & 4,1 & 3,9 & 4,6 & 6,9 & 6,5 \\
Lehmät & & 6,4 & 5,2 & 7,9 & 10,5 \\
\hline
\end{tabular}

\section{Alkionsiirrot}

Jalostusohjelman tehokkuus riippuu suurelta osin siirrettävien alkioiden määrästä, joten toteutus vaatii paljon alkionkantajia. Koska MTT:n karjoissa ei ole riittävästi alkionkantajia, Jokioisten ympärille on perustettu vastaanottajakarjojen verkosto (ASTU). Näihin karjoihin siirretään pääasiassa tuorealkioita. Pakastealkiot ovat mahdollistaneet ASTU-verkoston laajentumisen koko maahan jokaisen karjanomistajan ulottuville. Ydinkarjalla on osto-oikeus ASTU-alkiosta syntyneeseen lehmävasikkaan, joten osa ydinkarjan eläinaineksen uudistajista syntyy ytimen ulkopuolella. Vuonna 2002 testin aloittaneista ensikoista $6.7 \%$ oli alunperin ASTU-alkioista syntyneitä, jotka oli ostettu takaisin ytimeen hiehona.

Alkionsiirtojen määrä sekä MTT:n karjoissa että ASTU-verkostossa on lisääntynyt huomattavasti parina viime vuotena (taulukko 2). Erityisesti ASTU-pakastealkiot ovat kysyttyjä ja niiden siirrot ovat lisääntyneet. Jokioisten lähialueen ASTU-tiloille siirretään tuoreena myös sukupuolimääritettyjä alkioita, mutta näiden pakastuksen kestävyys ei ole vielä riittävän hyvä, jotta voitaisiin rutiinisti tuottaa sukupuolimääritettyjä pakastealkioita. Ydinkarjan tuorealkioiden tiineyttämiskyky on ollut noin 50 $\%$ ja pakastealkioiden hieman alhaisempi.

Vuonna 2002 siirrettiin ensimmäiset alkiot, joista oli sukupuolen ohella analysoitu myös tuotantoon kytkeytyneitä markkereita. Ensimmäiset geenikartoitetut lehmävasikat syntyivät heinäkuussa 2003.

Taulukko 2. Alkionsiirrot 1998-2003 (30.11.2003 asti)

\begin{tabular}{lrrrrrr}
\hline & $\mathbf{1 9 9 8}$ & $\mathbf{1 9 9 9}$ & $\mathbf{2 0 0 0}$ & $\mathbf{2 0 0 1}$ & $\mathbf{2 0 0 2}$ & $\mathbf{2 0 0 3}$ \\
\hline ASTU tuore & 4 & 112 & 108 & 74 & 103 & 53 \\
ASTU pakaste & 2 & 45 & 77 & 205 & 227 & 142 \\
MTT tuore & 123 & 35 & 141 & 122 & 230 & 178 \\
MTT pakaste & 76 & 48 & 101 & 101 & 162 & 133 \\
Yhteensä & $\mathbf{2 0 5}$ & $\mathbf{2 4 0}$ & $\mathbf{4 2 7}$ & $\mathbf{5 0 2}$ & $\mathbf{7 2 2}$ & $\mathbf{5 0 5}$ \\
\hline
\end{tabular}

\section{Valintatuloksia}

Ydinkarjan jalostusohjelma perustuu valtakunnalliseen lypsykarjan jalostusohjelmaan, jossa pääpaino on valkuaistuotoksessa sekä utarerakenteessa. Ydinkarjan jälkeläistuotannossa käytetään suomalaisia ja ruotsalaisia jälkeläisarvosteltuja sonneja, jotka jalostusvaliokunta on hyväksynyt sonninisiksi. Näiden lisäksi käytetään muita ayrshirerodun tuontisonneja, joilla on Suomessa isäsonnistatus.

Ydinkarjassa lehmien ja hiehojen valintapäätöksiin vaikuttavat ensisijaisesti eläimen jalostusarvo, maitotuotos, rakenne sekä terveys- ja käyttöominaisuudet. Rakenteessa kiinnitetään huomiota erityisesti utarerakenteeseen sekä jalkoihin. Pääperiaatteena on, että mikäli lehmä tulee karsituksi myös sen tyttäret karsiutuvat. Ydinkarja on avoin eli nuoria hiehoja ja alkioita ostetaan peruspopulaatiosta ytimeen. Näitä eläimiä valittaessa kiinnitetään huomiota erityisesti hiehon emän jalostusarvoon ja rakennetietoihin. 
Taulukossa 3 on esitetty ydinkarjan eläintilanne ja jalostusarvot vuoden 2003 viimeisen jalostusarvolaskennan jälkeen. Ydinkarjan eläinten jalostusarvot ovat korkeita ja valtakunnallisesti katsottuna ydinkarja on Suomen paras karja, kun mittarina käytetään eläinten jalostusarvoja. Ydinkarjan hiehojen ja ensikoiden jalostusarvot pysyttelevät arvostelusta toiseen +25 indeksipisteen molemmin puolin ja alkiontuotantoon valittujen lehmien jalostusarvojen keskiarvo on +33 . Testissä olevien ensikoiden maitotuotoksen jalostusarvojen keskiarvo oli 115,7 ja valkuaistuotoksen keskiarvo oli 118,0 vuoden 2003 viimeisessä jalostusarvolaskennassa. Ensikoiden utarerakenteen jalostusarvojen keskiarvo oli 111,5 .

Perinnöllinen edistyminen on ollut ydinkarjassa nopeaa kaikissa taloudellisesti tärkeissä ominaisuuksissa. Maitotuotoksessa ydinkarja on noin $470 \mathrm{~kg}$ ja valkuaistuotoksessa noin $19 \mathrm{~kg}$ perinnöllisesti edellä peruspopulaatiota. Utarerakenteessa ero on noin 12,5 indeksipistettä. Erityisesti tuotosominaisuuksissa perinnöllinen edistyminen on ollut nopeaa ydinkarjan ensimmäisissä ikäluokissa ja nuorimmissa ikäluokissa edistyminen on jo hieman tasaantunut (kuvio 1).

Taulukko 3. Ydinkarjan eläintilanne ja keskimääräiset jalostusarvot vuoden 2003 viimeisen jalostusarvolaskennen jälkeen.

\begin{tabular}{lcc}
\hline & Määrä & Jalostusarvo \\
\hline Nuoret hiehot ja lehmävasikat & 66 & +26 \\
Huuhteluikäiset hiehot & 23 & +26 \\
Tiineet hiehot & 68 & +24 \\
Ensikoita testissä & 39 & +27 \\
Valittuja ASMO-emiä & 7 & +33 \\
Entiset ASMO-emät & 24 & +31 \\
\hline
\end{tabular}
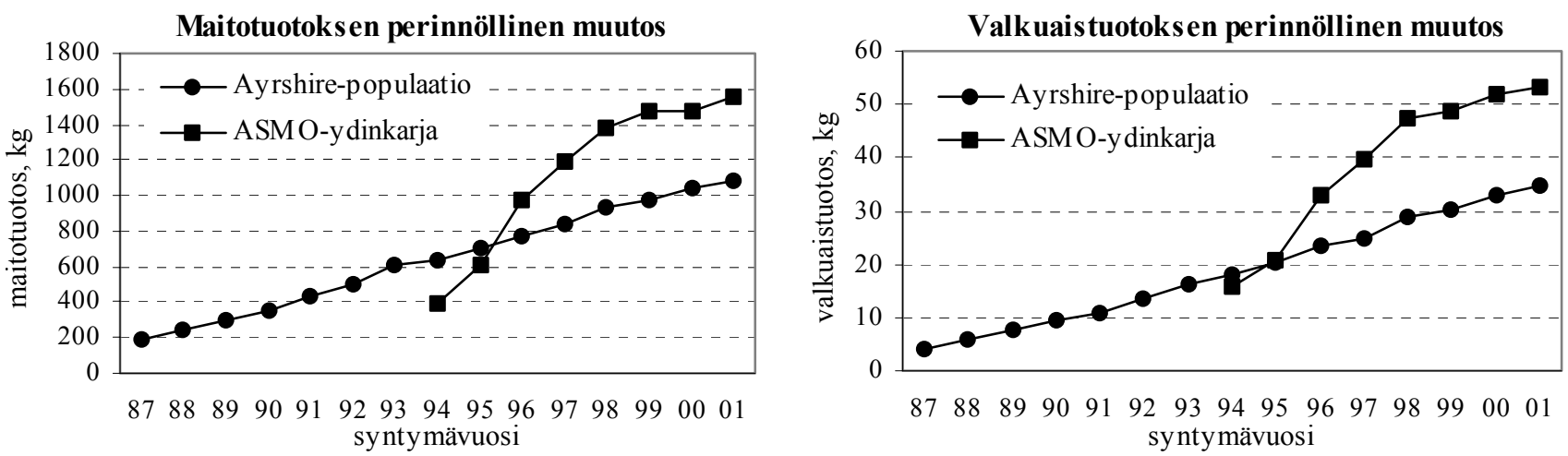

Kuvio 1. ASMO-ydinkarjan ja ayrshire-populaation maito- ja valkuaistuotoksen perinnöllinen muutos.

\section{Keinosiemennyssonnit}

Ydinkarjasta suoraan sekä ASTU-tiloilta on vuodesta 1997 lähtien myyty yhteensä 185 sonnia keinosiemennykseen. Jälkeläisarvostelun on saanut tähän mennessä 13 sonnia ja niiden jalostusarvojen keskiarvo oli +7 vuoden 2003 viimeisessä jalostusarvolaskennassa. Kansainvälisessä interbullarvostelussa ASMO Muffi ET sijoittuu 10. parhaaksi valkuaistuotannon mukaan arvosteltuna.

\section{Johtopäätökset}

Asmo-ydinkarja on toiminut nyt kuusi vuotta. Sekä lehmä- että hiehohuuhteluiden osalta tulokset ovat parantuneet vuosi vuodelta. Hyvät huuhtelutulokset kertovat osaltaan huuhteluryhmän kokemuksesta ja hyvästä ammattitaidosta sekä eläinten tasapainoisista olosuhteista ja hyvästä hoidosta. Viime vuosien hyviin huuhtelutuloksiin ovat myös vaikuttaneet hyvät rehuvuodet sekä monet muut tekijät. Ydinkarja tuottaa alkiomarkkinoille jatkuvasti korkeatasoisia alkioita ja karjanomistajat ovat oppineet hyödyntämään mahdollisuutta parantaa karjan eläinainesta alkioiden avulla. Vaikka ydinkarjalla on ostooikeus ASTU-alkiosta syntyneisiin lehmävasikoihin, noin $10 \%$ syntyneistä lehmävasikoista on ostettu takaisin ytimeen, joten suurin osa lehmävasikoista jää syntymätilalle. Ydinkarjassa pyritään lisäämään 
eri ominaisuuksiin kytkeytyneiden markkereiden analysointia ja alkioiden sukupuolen määrityksiä. Pitemmän ajan tavoitteena on kehittää sopiva pakastuskeino näin käsitellyille alkioille. Vuosittain huuhdeltavien hiehojen määrässä on saavutettu tavoite huuhdella 70-80 hiehoa vuodessa, mutta alkionluovuttajalehmiä ei ole valittu tavoitteen mukaisesti. Tavoitteena on valita vuosittain 15-20 lehmää alkionluovuttajiksi, mutta vuosittain on valittu vain 8-10 uutta luovuttajaa. Luovuttajien valintakriteerit ovat tiukat ja valinta on ollut ankaraa, mutta kustakin ikäluokasta on valittu alkiontuotantoon todella ikäluokan parhaimmat lehmät.

Ydinkarjan jalostusohjelma perustuu valtakunnalliseen jalostusohjelmaan, jonka tavoitteet ovat selkeät. Valintapäätökset on tehty näiden tavoitteiden mukaisesti ja se näkyy tuloksissa. Ydinkarjan eläinten jalostusarvot ovat korkeita ja perinnöllinen edistyminen on nopeaa. Ydinkarja on perinnöllisesti selvästi edellä ayrshirepopulaatiota kaikissa taloudellisesti tärkeissä ominaisuuksissa.

\section{Kirjallisuus}

Korpiaho, P., Strandén, I. \& Mäntysaari, E. A. 2003. Bull selection across age classes and variable female reproductive rate in an open nucleus breeding scheme for dairy cattle. Acta Agric. Scand. Section A Animal Science 53, 2: 74-82.

Pakula, M., Strandén, I. \& Mäntysaari, E. A. 1998. Stochastic simulation to optimize Finnsih dairy cattle nucleus breeding scheme. Proc. $49^{\text {th }}$ EAAP, Warsaw, Poland.

Parkkonen, P., Strandén, I. \& Mäntysaari, E. A. 2000. Alternative generation intervals in nucleus breeding scheme for dairy cattle. Proc. $51^{\text {st }}$ EAAP, The Hague, The Netherlands.

Strandén, I., Korpiaho, P., Pakula, M. \& Mäntysaari, E. A. 2001. Bull selection in MOET nucleus breeding scheme with limited testing capacity. Acta Agric. Scad. Section A Animal Science 51, 4: 235-245. 